University of Nebraska - Lincoln

DigitalCommons@University of Nebraska - Lincoln

Publications from USDA-ARS / UNL Faculty

U.S. Department of Agriculture: Agricultural

Research Service, Lincoln, Nebraska

2006

Sediment Transport Model for Seepage Erosion of Streambank

Sediment

G. A. Fox

Oklahoma State University, gafox2@ncsu.edu

G. V. Wilson

USDA-ARS

R. K. Periketi

Win Butler University

R. F. Cullum

USDA-ARS

Follow this and additional works at: https://digitalcommons.unl.edu/usdaarsfacpub

Part of the Agricultural Science Commons

Fox, G. A.; Wilson, G. V.; Periketi, R. K.; and Cullum, R. F., "Sediment Transport Model for Seepage Erosion of Streambank Sediment" (2006). Publications from USDA-ARS / UNL Faculty. 475.

https://digitalcommons.unl.edu/usdaarsfacpub/475

This Article is brought to you for free and open access by the U.S. Department of Agriculture: Agricultural Research Service, Lincoln, Nebraska at DigitalCommons@University of Nebraska - Lincoln. It has been accepted for inclusion in Publications from USDA-ARS / UNL Faculty by an authorized administrator of DigitalCommons@University of Nebraska - Lincoln. 


\title{
Sediment Transport Model for Seepage Erosion of Streambank Sediment
}

\author{
G. A. Fox, A.M.ASCE${ }^{1}$; G. V. Wilson ${ }^{2}$; R. K. Periketi ${ }^{3}$; and R. F. Cullum ${ }^{4}$
}

\begin{abstract}
Erosion by lateral, subsurface flow is known to erode streambank sediment in numerous geographical locations; however, the role of seepage erosion on mass failure of streambanks is not well understood. In the absence of an established sediment transport model for seepage erosion, the objectives of this research were to investigate the mechanisms of erosion due to concentrated, lateral subsurface flow and develop an empirical sediment transport model for seepage erosion of noncohesive sediment on near-vertical streambanks. Laboratory experiments were performed using a two-dimensional soil lysimeter of a reconstructed streambank profile packed with three different soil layers to mimic seepage erosion occurring at Little Topashaw Creek (LTC) in northern Mississippi. Soil samples from LTC streambanks indicated considerable hydraulic conductivity contrast between an overlying silt loam layer (SiL), highly permeable loamy sand, and confining clay loam layer. Lysimeter experiments were conducted with various upstream water table heads, overburden heights, and lysimeter slopes. Bank failure occurred prior to the total release of negative pore-water pressures in the SiL layer suggesting that such a mechanism was not critical for bank collapse due to seepage erosion. A seepage erosion transport model for conductive, noncohesive soil layers was derived based on a dimensionless sediment discharge and dimensionless seepage flow shear stress. The advantage of this sediment transport model is that it relates sediment flux to seepage discharge from the streambank.
\end{abstract}

DOI: 10.1061/(ASCE)1084-0699(2006)11:6(603)

CE Database subject headings: Bank erosion; Bank stabilization; Sediment transport; Seepage; Unsaturated flow.

\section{Introduction}

High infiltration rates can cause the development of perched water tables above water-restricting horizons in riparian soils (Wilson et al. 1991; Coates 1990). As perched water tables rise on these less permeable layers, large hydraulic gradients can initiate towards stream channels, causing fairly rapid subsurface flow (interflow) towards streams (Fig. 1). Hagerty (1991a) reports that slight changes in soil texture can result in considerable hydraulic conductivity contrasts between layers resulting in the formation of perched water tables in layered soils. Subsurface flow within perched water tables can contribute in gully formation (Istanbulluoglu et al. 2005; Froese et al. 1999; Bryan et al. 1998; Bull and Kirkby 1997; Romkens et al. 1997). Shallow subsurface flow plays a critical role in erosion in interacting with surface runoff mechanisms (Kirkby 1978; Kirkby and Chorley 1967).

\footnotetext{
${ }^{1}$ Assistant Professor, Dept. of Biosystems and Agricultural Engineering, Oklahoma State Univ., 111 Agricultural Hall, Stillwater, OK 74078-6016 (corresponding author). E-mail: garey.fox@okstate.edu

${ }^{2}$ Hydrologist, USDA-ARS National Sedimentation Laboratory, 598 McElroy Dr., Oxford, MS 38655. E-mail: gvwilson@ msa-oxford.ars.usda.gov

${ }^{3}$ Civil Engineer, Creegan and D'Angelo Consultants, 2420 Martin Rd., Ste. 380, Fairfield, CA 94533. E-mail: rperiket@olemiss.edu

${ }^{4}$ Agricultural Engineer, USDA-ARS National Sedimentation Laboratory, 598 McElroy Dr., Oxford, MS 38655. E-mail: bcullum@ msa-oxford.ars.usda.gov

Note. Discussion open until April 1, 2007. Separate discussions must be submitted for individual papers. To extend the closing date by one month, a written request must be filed with the ASCE Managing Editor. The manuscript for this paper was submitted for review and possible publication on July 29, 2005; approved on April 24, 2006. This paper is part of the Journal of Hydrologic Engineering, Vol. 11, No. 6, November 1, 2006. (CASCE, ISSN 1084-0699/2006/6-603-611/\$25.00.
}

Wilson et al. (2007) report considerable seepage flow (ranging from 4 to $931 \mathrm{~L} \mathrm{day}^{-1}$ ) of perched water near streams resulting in erosion of unconsolidated sediment at the bank face.

This lateral, subsurface flow can potentially result in erosion of unconsolidated material at the face of a streambank if the outflow is sufficient to mobilize particles and maintain the velocity necessary to transport mobilized particles away from the site (Dunne 1990; Higgins 1984, 1982; Zaslavsky and Kassiff 1965; Terzaghi 1943). Subsurface flow can erode sediment in two ways: (1) through the development of a critical body force or drag force that entrains particles in water seeping through and out of a porous medium, causing either liquefaction or Coulomb failure; and (2) through the application of shear stress to the margins of macropores, which may have originated independently of the water flow (Jones 1997; Zaslavsky and Kassiff 1965). From a geomorphologic perspective, subsurface hydraulic erosion is an important geomorphic process in the head watershed, because soil piping and water discharge via the pipes significantly affect hydrology, channel initiation, and slope evolution, as well as gully extension by tunnel scour erosion (Dunne 1990).

Hagerty $(1991 \mathrm{a}, \mathrm{b})$ discusses several conditions necessary for erosion by subsurface flow. First, there must be an exit point at which water can leave the soil mass and possibly dislodge particles. Streambanks provide an optimal exit point (Wilson et al. 2007). In addition to concentrated, lateral subsurface flow from infiltration in adjacent riparian zones, water from the stream can induce seepage or subsurface erosion when the stream stage is high enough to induce recharge into the streambank. Recharge water moves into zones of high conductivity if there is no counter flow of water towards the stream in that layer. This temporarily stored water is referred to as bank storage. When the water level declines in the river, bank stored water flows back to the stream 


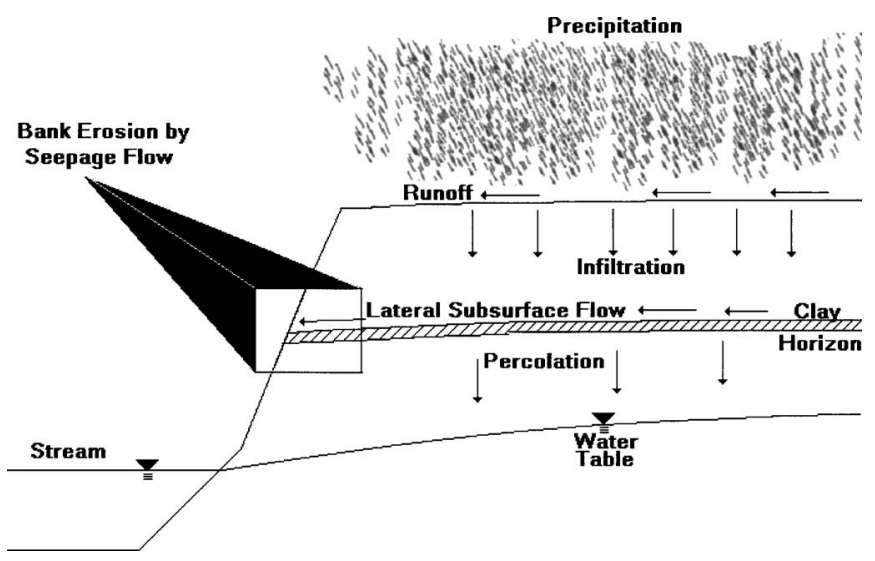

Fig. 1. Depiction of subsurface flow erosion mechanism of infiltrated water flowing in perched water tables in riparian zones adjacent to streams

and discharges in concentrated flow along the high conductivity layer.

Another condition necessary for subsurface erosion is the removal of displaced soil (Kochel et al. 1985). Erosion of bank material from the conductive layer by concentrated subsurface flow can produce cavities that facilitate failure of the unsupported bank material (Fig. 2). This condition links the fluvial entrainment of sediment and erosion by subsurface flow. Accumulated sediment from subsurface induced streambank failure must be removed for continued subsurface flow erosion. Research has begun to investigate the interaction of surface erosion, fluidization, and slumping whereby the onset of erosion is controlled not only by surficial flows but also hydrodynamic stress from groundwater seepage (Lobkovsky et al. 2004; Worman 1993). Indoor flume studies indicate that surface erosion rates increase by an order of magnitude when unsaturated pore-water pressures increase to near saturation, thereby decreasing the soil shear strength (Rockwell 2002; Owoputi and Stolte 2001). The final condition necessary for subsurface flow erosion is the critical hydraulic gradient. Concentrated, subsurface flow must have a gradient of sufficient intensity to displace in situ streambank sediment. Hagerty (1991a) suggests that the formation of cavities by subsurface flow erosion accelerates the supply of water to the exfiltration zone.

Most researchers investigating the role of seepage on erosion and undermining of hillslopes have focused on the seepage pressure as a body force acting on some representative sediment volume (Howard and McLane 1988; Iverson and Major 1986; McLane 1984; Zaslavsky and Kassiff 1965; Terzaghi 1943). Howard and McLane (1988) suggested that surface grains of cohesionless sediment eroded by groundwater are acted upon by three forces: gravity, a traction force defined as the sum of all forces on the seepage face, and a seepage force exerted on the sediment grain by groundwater seepage. Seepage forces predominate in a narrow "sapping zone" at the flow discharge point, and erosion occurs by bulk sediment movement in this zone. Howard and McLane (1988) expressed the seepage force as

$$
F_{s}=C_{2}^{\prime \prime} \frac{3 \pi}{n} \rho_{f} g i d^{3}
$$

where $\rho_{f}=$ fluid density; $g=$ gravitational acceleration; $d=$ grain size; $C_{2}^{\prime \prime}=$ empirical constant; $i=$ hydraulic head gradient; and $n=$ porosity. The resultant backcutting initiates failure of the

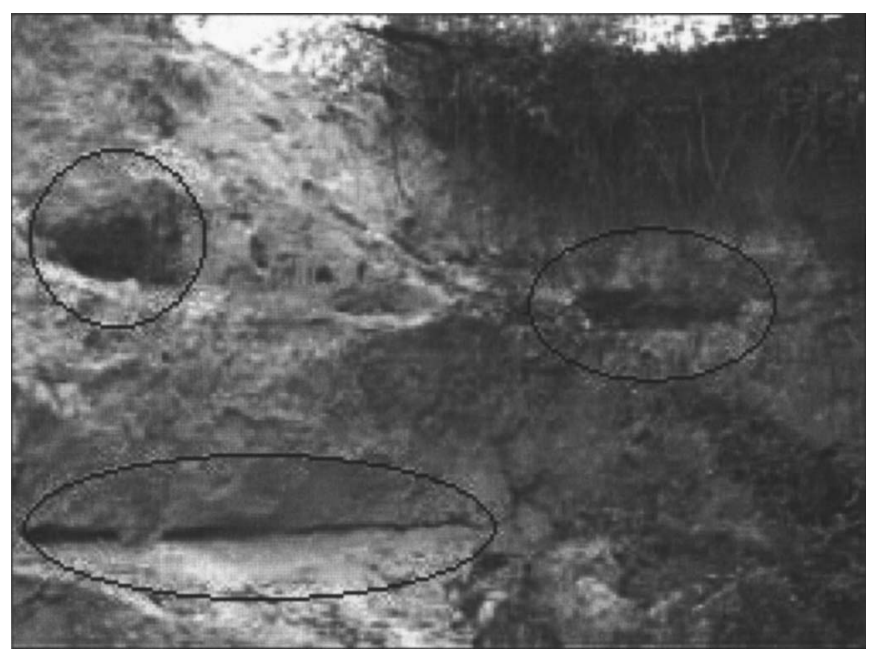

Fig. 2. Example of typical liquefaction of streambank sediment and headward migration of gully face along Little Topashaw Creek in northern Mississippi. Circled areas represent cavities from past seepage erosion events at Little Topashaw Creek.

"undermining zone" which occurs above the sapping zone (Periketi 2005; Howard and McLane 1988).

Even though theoretical models exist for the initiation of seepage erosion (Howard and McLane 1988), no sediment transport models exist for predicting the magnitude of seepage erosion as a function of seepage discharge. River bank erosion studies have measured seepage (Wilson et al. 2007; Bradford and Priest 1977; Burgi and Karaki 1971) or soil-water pressure (Casagli et al. 1999; Rinaldi and Casagli 1999), but consider only bank stability, mass failure, and seepage erosion without deriving a seepage sediment transport model. Howard and McLane (1988) propose a long-term sediment delivery flux from seepage erosion dependent on critical failure angles. Research on gully formation focuses more on the interaction of subsurface flow with surficial erosion processes (Rockwell 2002; Owoputi and Stolte 2001; Bryan 2000; Bryan et al. 1998). Many researchers have attempted to incorporate the additional forces of seepage flow through modification of the critical Shields criterion for studying primarily hillslope seepage erosion on small slopes (Istanbulluoglu et al. 2005; Lobkovsky et al. 2004). This research extends such seepage erosion experiments for simulating natural streambank profiles with much larger slopes and investigated the combined erosion of seepage and bank failure.

The objective of this research was to develop a sediment transport model, equivalent to sediment transport models based on bed shear strength in fluvial environments, specifically to describe seepage erosion of streambank sediment. The goal was to derive such a sediment transport model based on measurable characteristics of seepage erosion and bank failure for conditions of subsurface flow of perched water over water-restrictive layers. Therefore, approaches similar to sediment transport modeling for bed-load transport in fluvial environments (Meyer-Peter and Mueller 1948) were utilized. The sediment transport model in this research was derived from an innovative, two-dimensional lysimeter experiment of reconstructed streambank profiles at stream locations where seepage and bank erosion of streambank sediment commonly occur (Periketi 2005; Wilson et al. 2007). Similar lysimeter experiments were performed by Wilson et al. (2007); however, their experiments were limited to smaller bank heights and smaller inflow water heads which prevented obtaining 
discharge equivalent to measurements in situ. The long-term goal will be to incorporate sediment transport models for groundwater seepage with integrated fluvial sediment transport/bank stability/ riparian groundwater flow models (Langendoen et al. 2005).

\section{Materials and Methods}

\section{Site Description}

In the Yazoo River basin in Mississippi, erosion-induced bank failure contributes significantly to the sediment load entering streams (Simon and Thomas 2002). However, seepage erosion, one of the individual processes causing this accelerated streambank failure, is not well understood. This research focuses on seepage erosion occurring at Little Topashaw Creek (LTC), part of the Yalobusha Watershed in Chickasaw County, Mississippi. LTC is a fourth-order stream with a contributing drainage area of approximately $37 \mathrm{~km}^{2}$ (National Sedimentation Laboratory 2003). The surficial geology of the watershed is characterized by dispersive silt loam (SiL) and clay loam (CL) soils underlain by conductive loamy sand (LS) that in turn overlies consolidated cohesive material. The channel is tortuous, with an average sinuosity of 2.1, an average width of about $35 \mathrm{~m}$, an average bank height of $6 \mathrm{~m}$, and an average channel depth of $3 \mathrm{~m}$ (Shields and Knight 2004).

In this watershed, concave banks on the outside of meander bends are failing by mass wasting subject to basal endpoint control, and sand is accreting on large point bars opposite failing banks. Cutbanks frequently invade adjacent cultivated fields, while inside bends and abandoned sloughs are vegetated with a diverse mixture of hardwood trees and associated species. Streambanks of LTC are being eroded by lateral, subsurface flow due to the alternating layers of CL and LS on LTC streambank profiles (Wilson et al. 2007; National Sedimentation Laboratory 2003). Deep incision due to fluvial erosion in the main channel and historical channelization prevents water from rising to layers above the CL layers in the streambank. Therefore, seepage erosion in such areas is not due to reverse bank storage mechanisms, but rather lateral movement of infiltrated water along perched water tables.

Wilson et al. (2007) conducted soil property measurements of LTC streambanks. Soil bank profiles were generally described as a thick $(150 \mathrm{~cm})$ surface layer of silt loam (SiL) material that transitioned into a sandy loam (SL) from 150 to $200 \mathrm{~cm}$ depth. The profile below this depth generally exhibited a sequence of alternating thin $(10-15 \mathrm{~cm})$ layers of contrasting texture reflecting the alluvial deposition. Several locations were identified where seepage was occurring through a layer of LS (Wilson et al. 2007; Periketi 2005). These seeps correspond to LS layers overlying layers of increased clay content. Soil samples were analyzed for soil water retention, saturated hydraulic conductivities, bulk density, and soil texture. Soil water retention curves were derived using RETention Curve (RETC) (van Genuchten et al. 1991). Seep locations were also instrumented with lateral flow collection pans temporarily installed into the streambank face. Seep discharge and erosion were monitored following selected storm events. The range of seep discharge (4-931 L/day) and sediment transport rates $(380 \mathrm{mg} / \mathrm{L}-660 \mathrm{~g} / \mathrm{L})$ reported by Wilson et al. (2007) were used as guidance to mimic field discharge and seepage erosion in the laboratory lysimeter experiments.

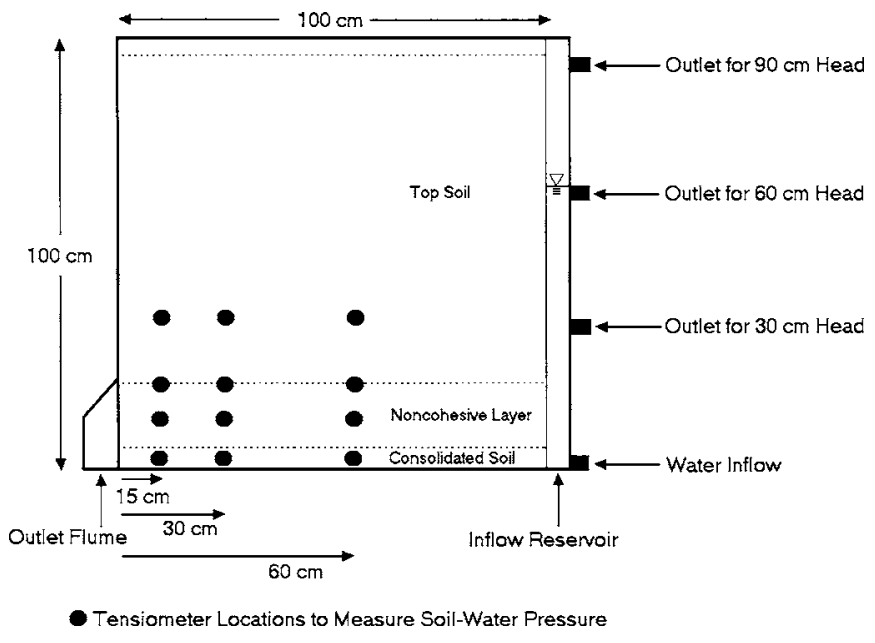

Fig. 3. Schematic diagram of lysimeter showing location of water inflow reservoir, water outflow section, and location of pencil-size tensiometers

\section{Lysimeter Experiments}

A lysimeter was constructed using 2-cm-thick Plexiglas to mimic LTC streambanks. The lysimeter was $100 \mathrm{~cm}$ long by $15 \mathrm{~cm}$ wide by $100 \mathrm{~cm}$ tall (Fig. 3). The lysimeter had a water reservoir on one end to maintain a constant water head during the experiments. An inflow tube allowed water to flow into the reservoir from the bottom. Overflow openings were located at $0,30,60$, and $90 \mathrm{~cm}$ from the bottom of the lysimeter. The outflow end of the lysimeter was flumed to allow sampling of flow and sediment.

A porous plate made of the $2.0 \mathrm{~cm}$ Plexiglas was inserted between the reservoir and the main body of the lysimeter. This porous plate had $0.32-\mathrm{cm}$-diameter holes filled with glass wool to prevent soil movement back into the reservoir. Before packing the lysimeter, a metal sheet was placed in front of the plate to protect the porous plate from clogging while packing. A front plate was used to cover the lysimeter from the front side. The lysimeter (Fig. 3) also had 12 1.5-cm-diameter openings on one face for installation of pencil-size tensiometers (Soil Measurement Systems, Tuscon, Ariz.). The tensiometers were limited to reading maximum soil-water pressures of $5 \mathrm{~cm} \mathrm{H}_{2} \mathrm{O}$. Twelve tensiometers were installed at heights of $2.5,10,15$, and $30 \mathrm{~cm}$, which correspond with the middle of the CL layer, middle of the LS layer, LS/SiL interface, and $20 \mathrm{~cm}$ above the $\mathrm{LS} / \mathrm{SiL}$ interface into the SiL. The tensiometers were located at distances of 15,30 , and $60 \mathrm{~cm}$ from the outlet in each layer. The soil-water pressure inside the tensiometer was monitored with a transducer (Soil Measurement Systems, Tuscon, Ariz.) connected to the tensiometer. These data were collected by a datalogger (Campbell Scientific, Logan, Utah) at $15 \mathrm{~s}$ intervals.

The lysimeter was packed in $2.5 \mathrm{~cm}$ lifts to bulk densities measured in the field with a 5-cm-thick CL layer and a 10-cm-thick LS layer. Two SiL layer thicknesses were investigated: 50 and $80 \mathrm{~cm}$. Before the start of the experiment, the lysimeter was saturated for $24 \mathrm{~h}$ with a solution consisting of $0.005 \mathrm{M} \mathrm{CaCl}_{2}$ and $0.2 \mathrm{~g} / \mathrm{L}$ of Thymol in order to prevent the dispersion of soil particles and microbial growth within pore spaces, and then drained for $24 \mathrm{~h}$ to achieve a consistent antecedent moisture condition. Two cameras were installed to monitor the experiment. One camera captured the side view of the lysimeter and another camera captured the discharge end of the 


\begin{tabular}{|c|c|c|c|c|c|c|c|c|}
\hline \multirow[b]{2}{*}{ Texture } & \multicolumn{2}{|c|}{ Composition } & \multirow[b]{2}{*}{$\begin{array}{c}\text { Bulk } \\
\text { density } \\
\left(\mathrm{g} \mathrm{cm}^{-3}\right)\end{array}$} & \multirow[b]{2}{*}{$\begin{array}{l}\text { Hydraulic } \\
\text { conductivity } \\
\left(\mathrm{cm} \mathrm{day}^{-1}\right)\end{array}$} & \multicolumn{2}{|c|}{ Water content } & \multicolumn{2}{|c|}{$\begin{array}{l}\text { van Genuchten } \\
\text { parameters }\end{array}$} \\
\hline & $\begin{array}{l}\text { Sand } \\
(\%)\end{array}$ & $\begin{array}{l}\text { Clay } \\
(\%)\end{array}$ & & & $\begin{array}{l}\text { Residual, } \theta_{\mathrm{r}} \\
\left(\mathrm{cm}^{3} \mathrm{~cm}^{-3}\right)\end{array}$ & $\begin{array}{c}\text { Saturation, } \\
\theta_{\mathrm{s}} \\
\left(\mathrm{cm}^{3} \mathrm{~cm}^{-3}\right)\end{array}$ & $\begin{array}{c}\alpha \\
(\mathrm{cm}-1)\end{array}$ & $\beta$ \\
\hline Silt loam (SiL) & 55 & 13 & 1.39 & 63.9 & 0.06 & 0.39 & 0.02 & 3.5 \\
\hline Loamy sand (LS) & 87 & 7 & 1.50 & $1,453.1$ & 0.03 & 0.40 & 0.04 & 3.0 \\
\hline Clay loam (CL) & 39 & 21 & 1.61 & 5.4 & 0.05 & 0.44 & 0.01 & 1.67 \\
\hline
\end{tabular}

lysimeter focused on the LS layer. Sample bottles were arranged to collect soil and water discharging from the lysimeter during the experiment.

Water was added to the inflow reservoir to achieve the desired head. The time at which water first discharged through the LS layer into the outlet flume was recorded. As the LS layer eroded and the undercutting occurred, flow and sediment samples were collected in sampling bottles at regular intervals. The undercutting of the LS layer was recorded by measuring the distance of undercutting from the end of the lysimeter. Experiments were performed until bank collapse occurred. The digital images obtained during the experiments were transferred to a scaled drawing of the chamber to document erosion profiles. The locations of tension cracks were documented. The bank failure dimensions were measured and recorded. Discharge and sediment samples were analyzed to quantify flow and erosion rates during the experiments. In total, eight lysimeter experiments were performed with reconstructed LTC streambank profiles by varying the inflow water head $(30,60$, or $90 \mathrm{~cm})$, bank height of SiL $(50$ or $80 \mathrm{~cm})$, and lysimeter slope $(0,5$, or $10 \%)$. The bank face was cut to vertical for the 5 and $10 \%$ slopes. A vertical lysimeter bank face mimicked the nearly vertical bank slopes commonly observed at LTC and other incised stream channels.

\section{Dimensionless Seepage Erosion Sediment Transport Model}

Discharge and sediment concentrations measured during seepage erosion in the lysimeter experiments were used to derive a sediment transport model. A dimensional analysis was performed by defining a sediment transport rate per unit width $\left(q_{s}\right)$. This transport rate depends upon the shear stress $(\tau)$, viscosity $(\mu)$, head $(h)$, density of water $(\rho)$, grain size $(d)$, density of sediment grain $\left(\rho_{s}\right)$, and acceleration due to gravity $(g)$

$$
q_{s}=f\left(\tau, \mu, h, \rho, \rho_{s}, d, g\right)
$$

We were only concerned with transport of grains in water and flow depths greater than a few times the grain size (as verified by Periketi 2005). Therefore, a relationship was derived between dimensionless sediment flux $\left(q_{s}^{*}\right)$ and shear stress $\left(\tau^{*}\right)$, where shear stress was assumed to be dependent on the seepage force proposed by Howard and McLane (1988)

$$
\begin{gathered}
q_{s}^{*}=a \tau^{* b} \\
q_{s}^{*}=\frac{q_{s}}{\sqrt{(s-1) g d^{3}}}
\end{gathered}
$$

$$
\tau^{*}=\frac{C_{2}^{\prime \prime} q}{(s-1) n K}
$$

where $a$ and $b=$ empirical regression parameters; $C_{2}^{\prime \prime}=$ empirical parameter that depends on the packing coefficient; $q=$ Darcy's velocity or discharge per unit flow area (assumed equal to the width of the lysimeter times the average flow depth at the lysimeter outlet); $K=$ hydraulic conductivity; $n=$ porosity of the seepage layer; and $s=$ ratio of solid to fluid density. This approach, i.e., Eq. (3), is similar to sediment transport models for bed-load transport in fluvial environments (Meyer-Peter and Mueller 1948). The model is derived for near vertical bank faces that are common in incised stream systems undergoing bank sloughing.

\section{Results and Discussion}

Saturated hydraulic conductivity measurements indicate a threeorder of magnitude contrast in conductivity with depth (Periketi 2005; Wilson et al. 2007). Water retention characteristics for the LS and CL also indicate considerable contrast between the layers (Table 1). The eight lysimeter experiments investigated the relative importance of slope, water head level, and bank height on the bank collapse time, cumulative erosion rate, and discharge. A summary of data collected from each lysimeter experiment is shown in Table 2. Sediment and discharge samples were not acquired for the $0 \%$ slope, $90 \mathrm{~cm}$ head, and $80 \mathrm{~cm}$ bank height due to the rapid failure. Seepage erosion was measured as the sediment discharge from the sapping zone that resulted in undercutting of the bank, whereas bank erosion was measured as the mass of sediment from bank collapse.

The lysimeter experiments mimicked seepage erosion and bank collapse observed in the field at LTC (Periketi 2005) as shown in Figs. 4 and 5. Discharge averaged $116 \mathrm{~L} /$ day with a coefficient of variation (COV) of $46 \%$ and was within measured and expected ranges at field seep locations (Wilson et al. 2007). As expected, average discharge in the lysimeter experiments was positively correlated to inflow water head (i.e., perched water table depth) and slope. Wilson et al. (2007) speculated that the lower flow rates observed in their lysimeter experiments than measured in situ were due to smaller heads than observed in situ. This hypothesis appears appropriate since measured discharge in the laboratory experiments correlated to in situ measurements of discharge.

Seepage erosion rates averaged $1.87 \mathrm{~kg} \mathrm{~L}^{-1}$ with a $\mathrm{COV}$ of $16 \%$ and were higher in the lysimeter experiments compared to conservative (i.e., on the regression limbs of stream flow hydrographs) in situ sampling following selected rainfall events 
Table 2. Summary of Boundary Conditions and Measured Flow and Seepage Erosion Characteristics during Lysimeter Experiments

\begin{tabular}{|c|c|c|c|c|c|c|c|c|}
\hline \multicolumn{3}{|c|}{ Boundary conditions } & \multicolumn{6}{|c|}{ Lysimeter measurements } \\
\hline $\begin{array}{l}\text { Bank } \\
\text { height } \\
(\mathrm{cm})\end{array}$ & $\begin{array}{l}\text { Water } \\
\text { head } \\
(\mathrm{cm})\end{array}$ & $\begin{array}{l}\text { Slope } \\
(\%)\end{array}$ & $\begin{array}{l}\text { Time to } \\
\text { failure } \\
\text { (s) }\end{array}$ & $\begin{array}{c}\text { Seepage } \\
\text { erosion } \\
(\mathrm{kg})\end{array}$ & $\begin{array}{c}\text { Tension } \\
\text { crack }^{\mathrm{a}} \\
(\mathrm{cm})\end{array}$ & $\begin{array}{c}\text { Bank } \\
\text { erosion } \\
(\mathrm{kg})\end{array}$ & $\begin{array}{l}\text { Undercut } \\
(\mathrm{cm})\end{array}$ & $\begin{array}{l}\text { Soil-water } \\
\text { pressure }^{b} \\
\left(\mathrm{~cm} \mathrm{H}_{2} \mathrm{O}\right)\end{array}$ \\
\hline 80 & 30 & 0 & 660 & 0.53 & 35.5 & 24.3 & 9 & -28 \\
\hline 80 & 60 & 0 & 570 & 1.07 & 21.5 & 23.1 & 14 & -37 \\
\hline 80 & 90 & 0 & 300 & 0.19 & 12.4 & 23.5 & 4 & -33 \\
\hline 80 & 60 & 5 & 600 & 2.20 & 11.5 & 7.5 & 14 & -36 \\
\hline 80 & 60 & 10 & 645 & 1.42 & 32.0 & 56.3 & 10 & -19 \\
\hline 50 & 60 & 0 & 840 & 3.17 & 9.0 & 4.7 & 13 & -29 \\
\hline 50 & 60 & 5 & 900 & 2.00 & 28.5 & 33.6 & 15 & -44 \\
\hline 50 & 60 & 10 & 1,050 & 3.76 & 35.0 & 36.8 & 28 & -22 \\
\hline
\end{tabular}

${ }^{\mathrm{a}}$ Distance from lysimeter outflow face.

${ }^{\mathrm{b}}$ Soil-water pressure refers to the pressure reading at tensiometer $(15 \mathrm{~cm}$ from streambank face and $30 \mathrm{~cm}$ from the bottom of the lysimeter in the silt loam) at the end of the experiment (i.e., bank failure time).

(Wilson et al. 2007). The LS layers did not exhibit macroscopic structure but organic matter and Fe oxides form interparticle bridges in situ that could not be mimicked during repacking in the laboratory. Additionally, geomorphology literature suggests that the entrainment of sediment during seepage erosion may be preceded by a period of weathering concentrated at the seepage face to reduce cohesion of the geological material (Dunne 1990; Howard 1986). Repacked streambed profiles may not need to ex- perience this same concentrated weathering prior to seepage erosion in order to produce high seepage erosion rates.

No in situ measurements were available for comparison with the bank erosion measurements, which averaged $26.2 \mathrm{~kg}$ with a COV of $68 \%$. Critical shear stress and erodibility parameters of field and repacked SiL were measured using a jet test method (Hanson et al. 2001). It was discovered that the measured value of the critical shear stress $(0.66 \mathrm{~Pa})$ for SiL was slightly lower than (a)

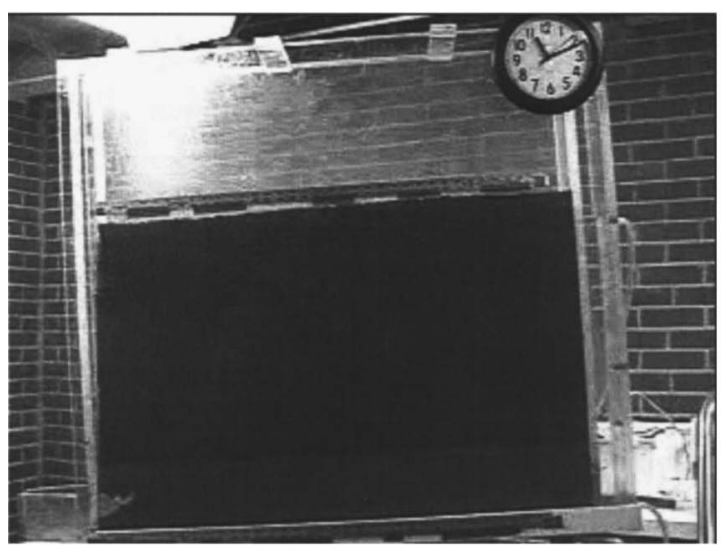

(b)

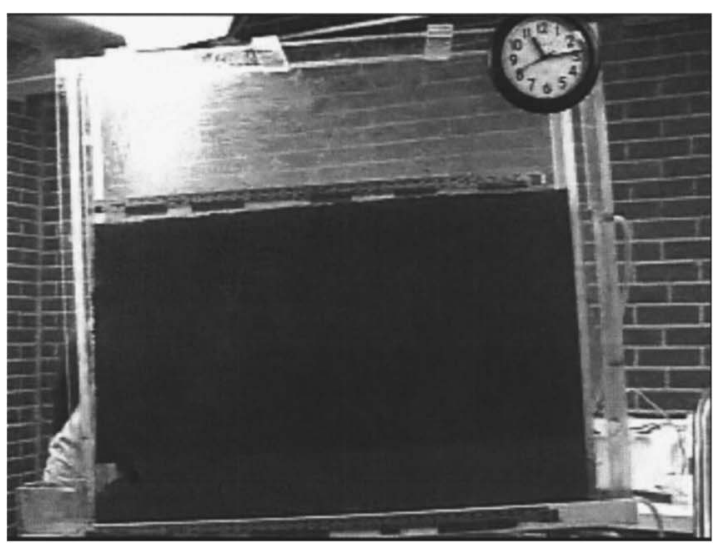

(c)

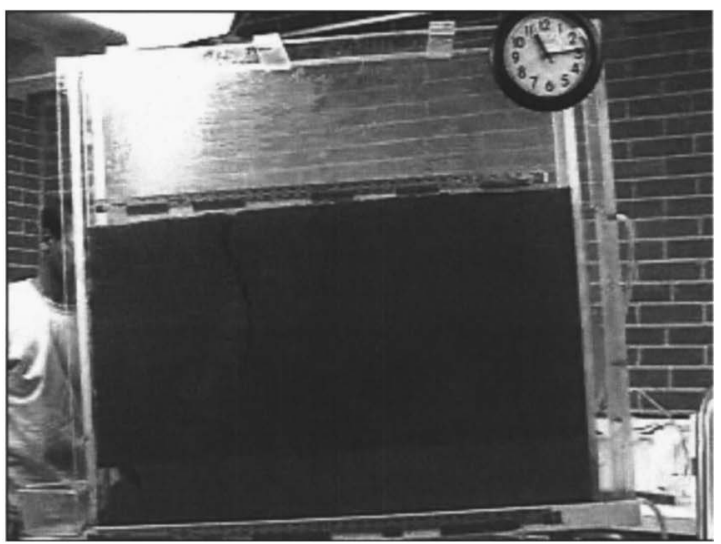

(d)

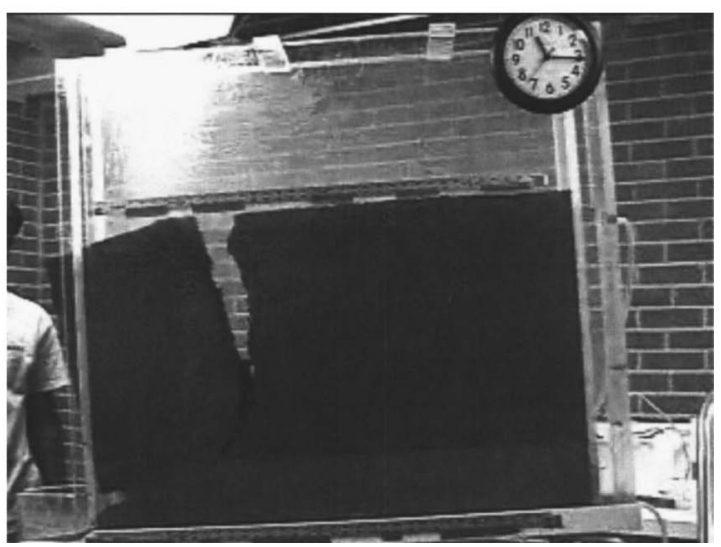

Fig. 4. Typical time series of bank failure due to subsurface erosion: (a) sapping erosion; (b) undermining; (c) tension crack formation; and (d) bank collapse. Images shown are for an experiment with $50 \mathrm{~cm}$ bank height, $60 \mathrm{~cm}$ water head, and $5 \%$ slope. 
(a)

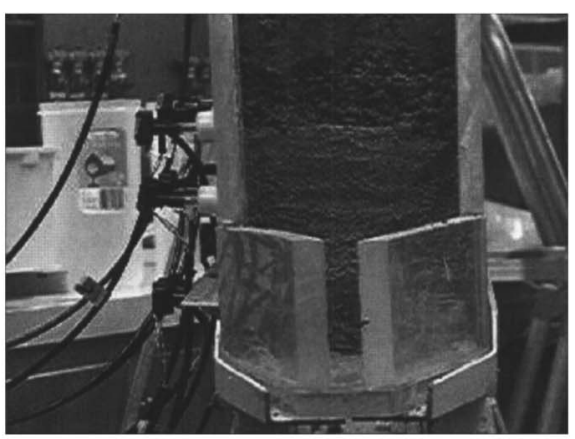

(b)

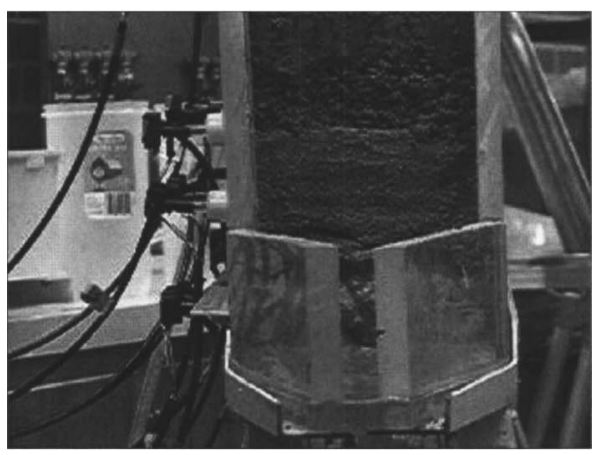

(c)

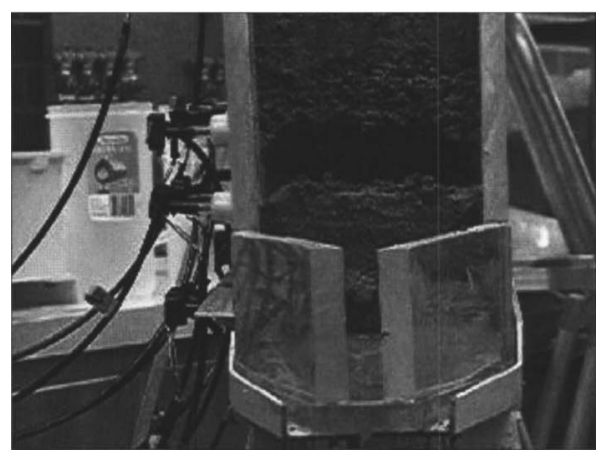

Fig. 5. Sapping erosion during typical lysimeter experiment: (a) at initiation of discharge; (b) during sapping erosion; and (c) during undermining. Images shown are for experiment with $80 \mathrm{~cm}$ bank height, $60 \mathrm{~cm}$ water head, and $0 \%$ slope.

typical values measured along LTC (Simon and Darby 1999). Therefore, repacked SiL may offer less resistance and collapse with greater bank failure mass than expected in field conditions.

As expected, the perched water table depth had a considerable influence on seepage and bank erosion. Increasing the water head correspondingly increased the rate of advancement of the wetting front. The first three experiments were conducted at the same slope $(0 \%)$ and bank height $(80 \mathrm{~cm})$, but at different inflow water head values $(30,60$, and $90 \mathrm{~cm})$. Bank failure time (Table 2) correlated to the depth of the perched water table (i.e., inflow water head). For the 30, 60, and $90 \mathrm{~cm}$ heads, the respective failure times were 660,570 , and $300 \mathrm{~s}$. For experiments with a 30 and a $60 \mathrm{~cm}$ head, 0.53 and $1.07 \mathrm{~kg}$ of sediment were eroded, respectively, from the sapping zone. Seepage erosion was lowest for the $90 \mathrm{~cm}$ head because a critical threshold was reached wherein the bank failure mechanism rate exceeded the rate of seepage erosion. Bank failure for the $90 \mathrm{~cm}$ head precluded the undercutting of the bank by seepage erosion.

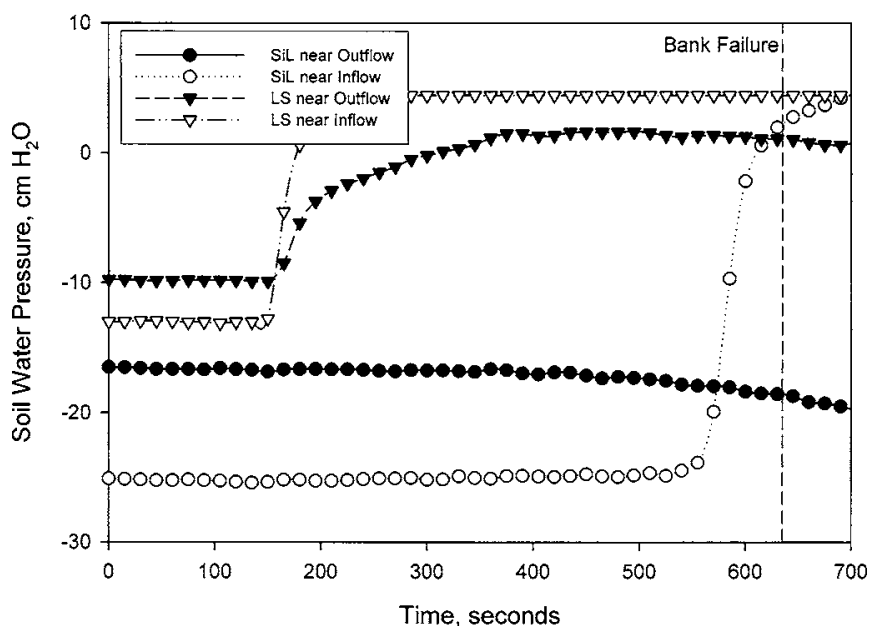

Fig. 6. Typical tensiometer data in loamy sand (LS) and silt loam (SiL) streambank layers near inflow reservoir of lysimeter $(60 \mathrm{~cm}$ from lysimeter outlet) and near outflow $(15 \mathrm{~cm}$ from lysimeter outlet). Data are for experiment with $80 \mathrm{~cm}$ bank height, $60 \mathrm{~cm}$ inflow water head, and $10 \%$ slope. Bank failure occurred 645 after initiation of experiment.

The impact of height of bank material was investigated for 50 and $80 \mathrm{~cm}$ of SiL with a $60 \mathrm{~cm}$ head (Table 2). The seepage erosion was greater for the shallower bank with an average of the three slopes being 2.98 and $1.56 \mathrm{~kg}$, respectively, for the 50 and $80 \mathrm{~cm}$ banks. The seepage erosion resulted in bank undercutting of 18.5 and $12.7 \mathrm{~cm}$, respectively. These results are similar to the average of $1.76 \mathrm{~kg}$ of seepage erosion and $13.8 \mathrm{~cm}$ of undercutting measured by Wilson et al. (2007) for a $30 \mathrm{~cm}$ bank with a $40 \mathrm{~cm}$ head. It is likely that the lower water head used by Wilson et al. (2007) resulted in lower seepage erosion rates than would have been observed at a $60 \mathrm{~cm}$ head. The bank failure as a result of bank undercutting averaged 25.0 and $29.0 \mathrm{~kg}$ for the 50 and $80 \mathrm{~cm}$ bank height, respectively. This bank failure mass is significantly greater than the minor bank erosion $(0.2 \mathrm{~kg})$ reported in the Wilson et al. (2007) lysimeter experiments. Compiling the $0 \%$ slope data for the two studies, there exists a strong linear correlation $\left(R^{2}=0.95\right.$, slope $=0.5$, and intercept $\left.=-16.5\right)$ between bank erosion and bank height. These results demonstrate that as bank height decreases, the mass of sediment from bank failure decreases but the contribution of seepage erosion to total sediment load from banks increases.

The impact of slope on bank collapse time was assessed through six experiments. Three experiments were conducted with 50 and $80 \mathrm{~cm}$ bank heights using the same inflow water head $(60 \mathrm{~cm})$ but with different lysimeter slopes $(0,5$, and $10 \%)$. It was expected that cumulative seepage erosion would increase as slope increased, but the pattern was inconsistent for both bank heights. However, the average seepage erosions for the $60 \mathrm{~cm}$ bank height were linearly correlated $\left(R^{2}=0.72\right.$, slope $=0.05$, intercept $=2.0$ ) to the slope. Additionally, the time to bank failure was strongly correlated to the slope with $R^{2}$ values of 0.94 and 0.96 for the 50 and $80 \mathrm{~cm}$ bank heights, respectively. The resulting bank erosion was strongly correlated $\left(R^{2}=0.90\right)$ to slope for the average response of the two bank heights.

Tensiometer data suggested that bank collapse occurred prior to the total release of negative pore-water pressures in the SiL layer near the outlet of the lysimeter (Fig. 6). Total release of negative pore-water pressure has been suggested as a critical 
Table 3. Power Law Regression Equations for Erosion Rate $E(\mathrm{~kg} / \mathrm{s})$ versus Discharge $Q\left(\mathrm{~cm}^{3} / \mathrm{s}\right)$

\begin{tabular}{lcccccc}
\hline \multicolumn{3}{c}{ Boundary conditions } & & & \multicolumn{2}{c}{ Regression results } \\
\cline { 1 - 2 } \cline { 5 - 6 } $\begin{array}{l}\text { Bank height } \\
(\mathrm{cm})\end{array}$ & $\begin{array}{c}\text { Water head } \\
(\mathrm{cm})\end{array}$ & $\begin{array}{c}\text { Slope } \\
(\%)\end{array}$ & & Equation & $R^{2}$ \\
\hline 80 & 30 & 0 & & $E=0.4539 Q^{1.343}$ & 0.87 \\
80 & 60 & 0 & & $E=0.7424 Q^{1.279}$ & 0.89 \\
50 & 60 & 0 & & $E=0.7897 Q^{1.154}$ & 0.86 \\
80 & 60 & 5 & & $E=0.1476 Q^{1.569}$ & 0.99 \\
50 & 60 & 5 & & $E=1.0450 Q^{1.122}$ & 0.91 \\
80 & 60 & 10 & & $E=0.9241 Q^{1.186}$ & 0.98 \\
50 & 60 & 10 & & $E=1.4442 Q^{1.074}$ & 0.96 \\
\hline
\end{tabular}

mechanism of bank failure commonly considered in streambank stability analyses (Simon and Darby 1999) and as a mechanism of increasing surface erosion potential (Rockwell 2002). Tension cracks generally formed between 15 and $30 \mathrm{~cm}$ horizontally from the lysimeter outflow face in the SiL and near the bank face (Table 2) where negative pore-water pressures were maintained throughout the experiment (i.e., SiL near the lysimeter outlet in Fig. 6). Tensiometers in the LS near the outflow face commonly became positive and then migrated slowly back to zero water pressure as the tensiometer lost contact with eroding LS due to seepage erosion (Fig. 6). Bank collapse generally occurred when the distance of undercutting in the middle of the LS extended to approximately 10-20 cm (Table 2).

Following the suggested hypothesis of Howard and McLane (1988), erosion rate versus discharge followed a power law relationship during all the experiments (Table 3) with an average correlation coefficient $\left(R^{2}\right)$ of 0.9 :

$$
E=a Q^{b}
$$

where $E=$ erosion rate; $Q=$ discharge; and $a$ and $b=$ regression parameters. Due to the strength of the relationship between discharge and seepage erosion, a sediment transport model was derived based on the theory of seepage erosion proposed by Howard and McLane (1988). The regression parameters shown in Table 3 are limited in that one such specific sediment rating curve cannot be directly applied to the general field conditions because of differences in boundary conditions, grain size, slope, and sediment composition. Applying the dimensionless sediment transport model to the data from lysimeter experiments, a power law relationship between $\tau^{*}$ and $q_{s}^{*}$ was observed (Fig. 7), which corresponded to governing relationships for empirical bed-load functions for fluvial erosion (Istanbulluoglu et al. 2003; Nelson and Smith 1989; Meyer-Peter and Mueller 1948).

Since seepage erosion occurred within the predominately noncohesive loamy sand layer at LTC, the cohesion of the soil was not included in the sediment transport model. Seepage erosion can occur in cohesive sediments if head gradients become sufficiently large to overcome this additional restrictive force and more research is needed on the interrelationship between seepage erosion and soil cohesion. The internal friction angle of the soil was not included in this research on vertical bank faces, but should be included in seepage erosion transport models for nonvertical bank slopes. It is hypothesized that the sediment flux should be dependent upon the degree to which the actual slope angle exceeds the internal friction angle of the seepage layer, which should represent the intermittent mass wasting due to seepage flow. Future lysimeter experiments are underway to derive such a sediment transport model. The critical shear stress and

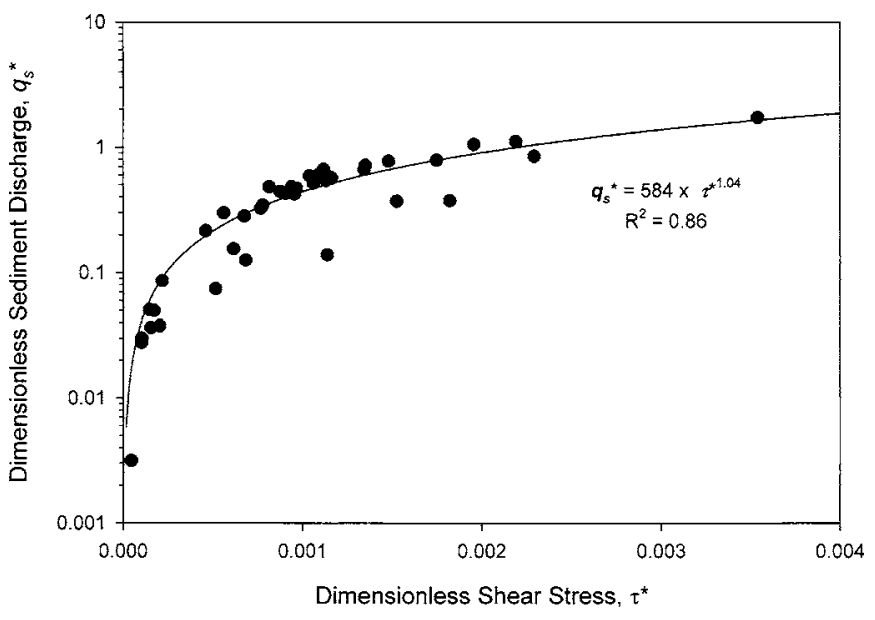

Fig. 7. Dimensionless sediment discharge $\left(q_{s}^{*}\right)$ versus dimensionless shear stress $\left(\tau^{*}\right)$ as measured from lysimeter experiments

erodibility of repacked silt loam was measured using a jet test method (Hanson et al. 2002). The jet test was not applicable to the unconsolidated LS material. The measured critical shear stress value of $0.66 \mathrm{~Pa}$ for the bank material was a little lower than typical values measured along LTC. Thus, the bank erosion in the lysimeter experiments would be higher than bank erosion in situ.

\section{Summary and Conclusions}

Lysimeter experiments simulating seepage erosion and bank collapse due to lateral flow of perched water mimicked conditions observed at a field site along Little Topashaw Creek in northern Mississippi. Experiments demonstrated definitive patterns of bank collapse time with respect to perched water table height and bank height. Increasing the water head correspondingly increased rate of advancement of the wetting front and resulted in faster bank collapse. Saturation of pore space decreased the effective cohesion of the SiL, but the development of tension cracks usually formed between 15 and $30 \mathrm{~cm}$ from the outflow of the lysimeter, prior to wetting front arrival. These results suggested that total release of negative pore-water pressure was not required for bank failure. As bank height decreased, the mass of sediment from bank failure decreased but the contributions of seepage erosion to total sediment load from banks increased. Bank failure occurred in all experiments when undercutting in the sapping and undermining zones reached $10-20 \mathrm{~cm}$. A sediment transport model based on dimensionless sediment transport rate and a dimensionless shear stress as a function of the seepage force acting on grains of noncohesive sediment was derived. A strong power law relationship $\left(R^{2}=0.86\right)$ suggested that such a relationship could be derived to extend the laboratory experiments for predicting in-field seepage erosion.

The primary concerns with applicability of the proposed sediment erosion model for utilization in natural field conditions include side-wall effects associated with the lysimeter, natural heterogeneity in streambank sediment along a stream reach such as interparticle bridges present in undisturbed soils, and whether the same model can be used for exfiltration due to reverse bank storage. These concerns have been identified and future work is aimed at evaluating such effects on the proposed seepage erosion model. The long-term goal of this research is to integrate the seepage erosion model with groundwater flow and streambank 
stability models to produce a numerical bank stability model with a seepage erosion component that can account for the interaction between groundwater and fluvial erosion. Such a combined model could then determine the time frame of seepage erosion relative to rising and falling stream stage.

\section{Acknowledgments}

This material is based upon work supported by the Cooperative State Research, Education, and Extension Service, U.S. Department of Agriculture, under Award No. 2005-35102-17209. This publication was also made possible through support provided by the U.S. Department of the Interior through Mississippi State University under the terms of Agreement No. 01HQGR0088. The opinions expressed herein are those of the writers and do not necessarily reflect the views of the U.S. Department of the Interior or Mississippi State University. The writers also acknowledge Dr. Weiming Wu, Research Assistant Professor, National Center for Computational Hydroscience and Engineering, University of Mississippi, University, Miss., and Dr. F. D Shields, Jr., Civil Engineer, USDA-ARS National Sedimentation Laboratory, Oxford, Miss., and three anonymous reviewers for reviewing an earlier version of this manuscript.

\section{References}

Bradford, J. M., and Priest, R. F. (1977). "Gully wall stability in loessderived alluvium." Soil Sci. Soc. Am. J., 41(1), 115-122.

Bryan, R. B. (2000). "Soil erodibility and processes of water erosion on hillslope." Geomorphology, 32(3-4), 385-415.

Bryan, R. B., Hawke, R. M., and Rockwell, D. L. (1998). "The influence of subsurface moisture on rill system evolution." Earth Surf. Processes Landforms, 23(9), 773-789.

Bull, L. J., and Kirkby, M. J. (1997). "Gully processes and modelling." Prog. Phys. Geogr., 21(3), 354-374.

Burgi, P. H., and Karaki, S. (1971). "Seepage effect on channel bank stability." J. Irrig. and Drain. Div., 97(1), 59-72.

Casagli, N., Rinaldi, M., Gargini, A., and Curini, A. (1999). "Pore water pressure and streambank stability: Results from a monitoring site on the Sieve River, Italy." Earth Surf. Processes Landforms, 24(12), 1095-1114.

Coates, D. R. (1990). "The relation of subsurface water to downslope movement and failure." Groundwater geomorphology: Role of subsurface water in earth-surface processes and landforms, C. G. Higgins and D. R. Coates, eds., Geological Society of America Special Paper 252, Boulder, Colo.

Dunne, T. (1990). "Hydrology, mechanics, and geomorphic implications or erosion by subsurface flow." Groundwater geomorphology: Role of subsurface water in earth-surface processes and landforms, C. G. Higgins and D. R. Coates, eds., Geological Society of America Special Paper 252, Boulder, Colo.

Froese, J. C., Cruse, R. M., and Ghaffarzadeh, M. (1999). "Erosion mechanics of soils with an impermeable subsurface layer." Soil Sci. Soc. Am. J., 63(6), 1836-1841.

Hagerty, D. J. (1991a). "Piping/sapping erosion. 1. Basic considerations." J. Hydraul. Eng., 117(8), 991-1008.

Hagerty, D. J. (1991b). "Piping/sapping erosion. 2. Identification diagnosis." J. Hydraul. Eng., 117(8), 1009-1025.

Hanson, G. J., Cook, K. R., and Hahn, W. (2001). "Evaluating headcut migration rates of earthen embankment breach tests." Proc., ASAE Annual Meeting, American Society of Agricultural Engineers, St. Joseph, Mich., Paper No. 012080.

Hanson, G. J., Cook, K. R., and Simon, A. (2002). "Non-vertical jet testing of cohesive streambank materials." Proc., ASAE Annual Meeting, American Society of Agricultural Engineers, St. Joseph, Mich., Paper No. 022119.

Higgins, C. G. (1982). "Drainage systems developed by sapping on Earth and Mars." Geology, 10(3), 147-152.

Higgins, C. G. (1984). "Piping and sapping: Development of landforms by groundwater outflow." Groundwater and as a geomorphic agent, R. G. Lafluer, ed., Allen and Unwin, Inc., Boston.

Howard, A. D. (1986). "Groundwater sapping on Mars and Earth.” Proc., and Field Guide, NASA Groundwater Sapping Conf., A. D. Howard, R. C. Kochel, and H. E. Holt, eds, National Aeronautics and Space Administration, Flagstaff, Ariz., pp. vi-xiv.

Howard, A. D., and McLane, C. F., III. (1988). "Erosion of cohesionless sediment by ground water seepage." Water Resour. Res., 24(10), $1659-1674$.

Istanbulluoglu, E., Bras, R. L., Flores-Cervantes, H., and Tucker, G. E. (2005). "Implications of bank failures and fluvial erosion for gulley development: Field observations and modeling." J. Geophys. Res., 110(Fl).

Istanbulluoglu, E., Tarboton, D. G., Pack, R. T., and Luce, C. (2003). "A sediment transport model for incising gullies on steep topography." Water Resour. Res., 39(4), 1103.

Iverson, R. M., and Major, J. J. (1986). "Groundwater seepage vectors and the potential for hillslope failure and debris flow mobilization." Water Resour. Res., 22(11), 1543-1548.

Jones, J. A. A. (1997). "Subsurface flow and subsurface erosion." Process and form in geomorphology, D. R. Stoddart, ed., Routledge, London.

Kirkby, M. J. (1978). "Implications for sediment transport." Hillslope hydrology, M. J. Kirkby, ed., Wiley, Chichester, U.K., 325-364.

Kirkby, M. J., and Chorley, R. J. (1967). "Throughflow, overland flow, and erosion." Int. Assoc. Sci. Hydrol. Bull. 12(3), 5-21.

Kochel, R. C., Howard, A. D., and McLane, C. F. (1985). "Channel networks developed by groundwater sapping in fine-grained sediments: Analogs to some Martian valleys." Models in geomorphology, M. J. Woldenberg, ed., Allen and Unwin, Boston, 313-341.

Langendoen, E. J., Lowrance, R. R., Williams, R. G., Pollen, N., and Simon, A. (2005). "Modeling the impact of riparian buffer systems on bank stability of an incised channel." Proc., World Water \& Environmental Resources Congress (CD-ROM), Anchorage, Alaska, American Society of Civil Engineers, Reston, Va.

Lobkovsky, A. E., Jensen, B., Kudrolli, A., and Rothman, D. H. (2004). "Threshold phenomena in erosion driven by subsurface flow." J. Geophys. Res., 109(F4).

McLane, C. F. (1984). "An experimental and theoretical study of seepage-induced erosion in non-cohesive sediments.” $\mathrm{Ph}$. D. dissertation, Univ. of Virginia, Charlottesville, Va.

Meyer-Peter, E., and Mueller, R. (1948). "Formulas for bed-load transport." Proc., 2nd Int. Association Hydraulic Research, Stockholm, Sweden.

National Sedimentation Laboratory. (2003). "Little Topashaw Creek." 〈http://www.sedlab.olemiss.edu/wqe_unit/topashaw.html〉 (Aug. 17, 2003).

Nelson, J. M., and Smith, J. D. (1989). "Evolution and stability of erodible channel beds." River meandering, S. Ikeda and G. Parker, eds., Vol. 12, Water Resources Monograph Series, American Geophysical Union, Washington, D.C.

Owoputi, L. O., and Stolte, W. J. (2001). "The role of seepage in erodibility." Hydrolog. Process., 15(1), 13-22.

Periketi, R. (2005). "Analysis of seepage erosion with lysimeter experiments and numerical modeling." M.S. thesis, Univ. of Mississippi, University, Miss.

Rinaldi, M., and Casagli, N. (1999). "Stability of streambanks formed in partially saturated soils and effects of negative pore water pressures: The Sieve River (Italy)." Geomorphology, 26(4), 253-277.

Rockwell, D. L. (2002). "The influence of groundwater on surface flow erosion processes." Earth Surf. Processes Landforms, 27(5), 495-514. 
Romkens, M. J. M., Prasad, S. N., and Helming, K. (1997). "Effect of negative soil water pressures on sediment concentration in runoff." Management of landscapes disturbed by channel incision, S. S. Y. Wang, E. H. Langendoen, and F. D. Shields, eds., Univ. of Mississippi Press, Oxford, Miss., 1002-1007.

Shields, F. D., Jr., and Knight, S. S. (2004) "Ten years after: Stream habitat restoration project in retrospect." Proc., World Water \& Environmental Resources Congress (CD-ROM), Philadelphia, American Society of Civil Engineers, Reston, Va.

Simon, A., and Darby, S. E. (1999). "The nature and significance of incised river channels." Incised river channels: Processes, forms, engineering and management, S. E. Darby and A. Simon, eds, Wiley, New York.

Simon, A., and Thomas, R. J. (2002). "Processes and forms of an unstable alluvial system with resistant, cohesive streambeds." Earth Surf. Processes Landforms, 27(7), 699-718.

Terzaghi, K. (1943). Theoretical soil mechanics, Wiley, New York. van Genuchten, M. Th., Leij, F. J., and Yates, S. R. (1991). "The RETC code for quantifying the hydraulic functions of unsaturated soils, Version 1.0.” EPA Rep. No.600/2-91/065, U.S. Salinity Laboratory, USDA, ARS, Riverside, Calif.

Wilson, G. V., Jardine, P. M., Luxmore, R. J., Zelazny, L. W., Lietzke, D. A., and Todd, D. E. (1991). "Hydrogeochemistry processes controlling subsurface transport from an upper subcatchment of Walker Branch watershed during storm events: 1 . Hydrologic transport processes." J. Hydrol., 123(3-4), 297-316.

Wilson, G. V., Periketi, R. K., Fox, G. A., Cullum, R. F., and Shields, F. D. (2007). "Seepage erosion properties contributing to streambank failure." Earth Surf. Processes Landforms, in press.

Worman, A. (1993). "Seepage-induced mass wasting in coarse soil slopes." J. Hydraul. Eng., 119(10), 1155-1168.

Zaslavsky, D., and Kassiff, G. (1965). "Theoretical formulation of piping mechanisms in cohesive soils." Geotechnique, 15(3), 305-316. 